\title{
Analysis of phosphorus migration into soil profiles fertilized with struvite
}

\author{
Matgorzata Worwąg ${ }^{1, *}$, Jolanta Sobik-Szołtysek ${ }^{1}$ \\ ${ }^{1}$ Institute of Environmental Engineering, Czestochowa University of Technology, Brzeznicka 60a, 42-200 Czestochowa, Poland
}

\begin{abstract}
The focus of the present study was on phosphorus migration into soil profile fertilized with struvite with various doses $(0.0 \mathrm{~g}$ - control, $0.1 \mathrm{~g}, 0.5 \mathrm{~g}$ and $1.0 \mathrm{~g})$. Lysimeter examinations were carried out in 3 columns which modelled 3 levels of soil washing $(10,20$ and $30 \mathrm{~cm})$ for each soil mixture with specific struvite doses. Each experiment consisted in flushing water through a column filled with a mixture, with an amount modelling the average annual rainfall for the area of the city of Czestochowa, Poland, adopted at the level of $650 \mathrm{~mm}$. The tests were conducted for 12 days, with simulation of monthly rainfall performed on each day. The phosphorus content was analyzed in the leachate. It was found based on the results that the amount of leached phosphorus was directly connected with the struvite dose in the mixture. The highest phosphorus concentrations were observed at the level of $20 \mathrm{~cm}$ of the height of soil profile for the dose of $0.1 \mathrm{~g}$ struvite. In the case of the higher struvite doses, i.e. $1.0 \mathrm{~g}$, the highest concentration was found for the height of $30 \mathrm{~cm}$. A decline in concentration of the leached phosphorus was observed after the sixth sampling of the eluate, which resulted from leaching the soil profile with simulated annual rainfall amount.
\end{abstract}

\section{Introduction}

Phosphorus is one of the basic nutrients for plants and an element which substantially impacts on eutrophication of waters, which is an unwanted effect [1]. It is claimed that the content of the active phosphorus in the soil, necessary for proper growth of plants, ranges from 6 to 8 $\mathrm{mg} / \mathrm{kg}$. In agriculture, phosphorus has been used in mineral and organic forms. It has a strong effect on soil properties and processes occurring in the soil, being a factor that determines intensity of accumulation of organic carbon and nitrogen. The amount of phosphorus present in the soil depends on its type, physicochemical properties and a way the soil is used [2]. Primary sources of phosphorus in soils include phosphorus minerals present in parent rocks, mainly apatites. Secondary sources are composed of dead matter of vegetation and animals, rainfall water, ground water, surface water and fertilizers in the form of pig manure, poultry manure and bird guano [3], and, more recently, mineral fertilizers manufactured based on natural phosphorites, extracted mainly in the West Africa. The source of phosphorus also include agricultural and industrial waste, sewage and sewage sludge, post-harvest residue, compost and waste of agricultural products, included in the food chain [4].

Phosphorus removed from the soil with the plants or due to erosion, surface flow or washing, can be supplemented only from the external sources. It is estimated that the use of phosphorus fertilizers will be increasing by ca. $1.5-3.6 \%$ per year [5], whereas according to various estimates, the resources of fossil fuels rich in phosphorus will be depleted in ca. 60-90 years [6]. Therefore, it is critical to find alternative sources of phosphorus obtained from e.g. waste or synthesized in chemical reactions following sewage treatment as struvite $\left(\mathrm{MgNH}_{4} \mathrm{PO}_{4} \cdot 6 \mathrm{H}_{2} \mathrm{O}\right)$. Struvite is a mineral with crystalline structure, obtained through synthesis [7]:

$$
\mathrm{Mg}+\mathrm{NH}_{4}++\mathrm{PO}_{4}{ }^{3-}+6 \mathrm{H}_{2} \mathrm{O} \rightarrow \mathrm{MgNH}_{4} \mathrm{PO}_{4} \cdot 6 \mathrm{H}_{2} \mathrm{O} \downarrow
$$

A specific ratio of magnesium, ammonium and phosphate concentrations is needed, with $1 \mathrm{~mol} \mathrm{Mg}^{2+}, 1$ mol $\mathrm{NH}_{4}{ }^{+}$and $1 \mathrm{~mol}\left(\mathrm{PO}_{4}{ }^{3-}\right.$, respectively [8]. This mineral is an alternative source of phosphorus in the soil environment [9]. This is the most effective form of phosphorus, bioavailable to plants since fertilizing components are released slowly, which limits the necessity of frequent fertilization. Struvite can be used directly in agriculture as a mineral fertilizer [10].

Depending on the form and varied soil and water conditions, phosphorus can be released to soil solution and ground water, and then migrate in the process of leaching towards the soil profile and be subjected to the process of washing to the waterways and other surface waters [11]. A fast movement of solutions concerns both water from the surface and movement of underground water [12]. According to some authors [13], the process of phosphorus leaching is not the actual washing (as it is in the case of e.g. nitrogen), but a type of the flow of

\footnotetext{
*Corresponding author: mworwag@is.pcz.czest.pl, jszoltysek@is.pcz.czest.pl
} 
phosphorus compounds through privileged pathways of underground flow, including the networks of regular cracks and macropores, huge cracks in the soil, chasms and channels carved by the soil fauna, root channels and wedges, lenses and layers that are characterized by improved parameters of filtration compared to the soil mass around them. These migration pathways determine the intensity and time of movement of solutions during rainfalls and thaws [14].

As demonstrated by Toor et al. (2003) [15], most of phosphorus removed from soil through leaching (55$76 \%$ ) is phosphorus in the form of non-reactive particles, composed of mainly monoesters and diesters of organic phosphorus. The phosphorus content in the soil profile decreases with the depth. The natural factors that impact on biogen migration, including phosphorus, include natural and anthropogenic factors such as:

- soil mineralization of organic matter [16];

- atmospheric conditions, especially the amount and distribution of precipitation (after intensive rainfalls and thaws in spring, intensification of loss of biogenic substances) and air temperature (especially in the growing period);

- form of the nitrogen fertilizer used;

- shape and inclination of the terrain: greater inclination means faster and greater surface flow i.e. greater erosion and leaching;

- physicochemical soil properties i.e. soil reaction, content of organic matter (mainly soluble forms) and content of individual forms of $\mathrm{Fe}$ and $\mathrm{Al}[16,17]$;

- way the land is used, character of agricultural activity, including the species of plants and degree of covering the soil with vegetation;

- microorganisms and soil microfauna [18], which can potentially stimulate phosphorus circulation in the soil through intensified solubility of the phosphorus compounds present in minerals through soil acidification, enzymatic distribution of organic phosphorus and generation of biogenic structures in the soil, changing availability of phosphorus and having impact on the migration of this element through infiltration and surface flow.

In certain environmental conditions, various amounts of phosphorus can be leached by water filtrating through the soil profile, which leads to a gradual reduction in its resources in soil environment and limitation of availability to plants [19]. Therefore, it seems important to evaluate the level of this migration especially in the case when actions are taken to replenish the lacks of phosphorus in the soil through dosing its compounds in the form of e.g. struvite. This study presents initial results of the analysis of phosphorus migration in the soil profile enriched with different doses of struvite.

\section{Materials and methods}

The cycle of examinations was conducted in lysimetric columns that reflect soil profile, filled with the soil fertilized by specific doses of struvite obtained through chemical synthesis. Water was flowing through the columns in dynamic conditions, simulating the assumed dose of the atmospheric precipitation.

\subsection{Substrates for research}

The soil for the examinations was obtained from a house garden, which after drying until the air dry state, was sieved through a sieve with $2 \mathrm{~mm}$ mesh. According to the Classification of Polish Society of Soil Science, the 2008 and USDA (United States Department of Agriculture) material was loamy sand.

This initial material was used to obtain 3 mixtures with different weight ratio, for $250 \mathrm{~g}$ of soil:

- mixture with content of $0.1 \mathrm{~g}$ struvite, denoted as $\mathrm{M} / 0.1(53,2 \mathrm{~kg} / \mathrm{ha})$

- mixture with content of $0.5 \mathrm{~g}$ struvite, denoted as $\mathrm{M} / 0.5(266,2 \mathrm{~kg} / \mathrm{ha})$

- mixture with content of $1 \mathrm{~g}$ struvite, denoted as $\mathrm{M} / 1.0(533,5 \mathrm{~kg} / \mathrm{ha})$

The control sample (soil without struvite addition) was denoted as $\mathbf{M} / \mathbf{0 . 0}$. Basic physical and chemical analyses were performed for samples of soil and soil mixtures (see Table 1).

Synthetic struvite was obtained from solutions prepared based on distilled water and phosphate salt in the form of $\mathrm{KH}_{2} \mathrm{PO}_{4}$, ammonium salt in the form of $\mathrm{NH}_{4} \mathrm{Cl}$ and magnesium salt in the form of $\mathrm{MgSO}_{4} \mathrm{x}$ $6 \mathrm{H}_{2} \mathrm{O}$. Previous studies have determined the most beneficial proportion of ions and $\mathrm{pH}$ which yield the highest struvite mass. Ion concentrations used to obtain struvite were: $100 \mathrm{mg} \mathrm{PO}_{4}{ }^{3-} / \mathrm{L}, 500 \mathrm{mg} \mathrm{NH}_{4}{ }^{+} / \mathrm{L}, 20 \mathrm{mg}$ $\mathrm{Mg}^{2+} / \mathrm{L}$, and $\mathrm{pH}=10$. Phase composition of the precipitate sediment was analyzed by means of an X-ray ADVANCE D8 diffractometer (Bruker).

Simulation of the rainfall was performed using deionized water, with its dose calculated according to annual rainfall levels in the area where soil sample was obtained.

\subsection{Physical and chemical analysis}

The graining of the test material has been determined by the organoleptic method in accordance with the Classification of the Polish Society of Soil Science, the 2008 and USDA (United States Department of Agriculture). Analyses of soil material included: determination of the content of organic matter (OM), $\mathrm{pH}$ in water and $\mathrm{KCl}$, total alkaline cations, total carbon content, total phosphorus, available phosphorus and nitrogen. The following methods were used for each test:

- organic matter (OM) [20];

- $\mathrm{pH}$ in $\mathrm{H}_{2} \mathrm{O}$ and $1 \mathrm{M} \mathrm{KCl}$ for the soil was determined using the potentiometric method by means of a multiparameter meter (HANNA INSTRUMENTS HI 9828) [21];

- total alkaline cations were evaluated using the Kappen method [22];

- total carbon content was evaluated by means of the Multi N/C 2100 analyzer (Analityk Jena) [23];

- total phosphorus content was evaluated [24]; 
- available phosphorus extraction by the Egner-Riehm method determined on a spectrophotometer [25];

- total nitrogen was determined by the Kjeldhal method [26] using the BÜCHI 435 mineralizer and the BÜCHI 355 distillation system.

Each evaluation was repeated for three times, and the analysis was based on mean values.

\subsection{Research procedure- column test}

Column tests were used to investigate the impact of dynamic conditions of water flow through the soil substrate, causing washing or precipitation of struvite. The study used a column made of acrylic glass with the length of $1.0 \mathrm{~m}$ and inner diameter of $5 \mathrm{~cm}$. The bottom of the column is equipped in a valve to collect leachate. Lysimeter examinations in the columns were carried out in 3 columns modeling 3 levels of soil washing $(10,20$ and $30 \mathrm{~cm}$ ) for each soil mixture with an appropriate dose of struvite and soil without struvite. Each experiment consisted of flushing water through a column filled with a mixture, with an amount modeling the average annual rainfall for the area from which the soil sample was taken, which was assumed at the level of $650 \mathrm{~mm}$. The amount of water needed for precipitation simulation was obtained by converting the average annual rainfall to the surface of lysimeter columns of $0.001963 \mathrm{~m}^{2}$. The dose calculated in this way was divided into 12 portions corresponding to monthly precipitation, which were administered to the column for the next 12 days. Before the experiment began, the material in the columns was watered to similar water content $(97.65 \%)$. Leachates from the columns were collected every 2 days and designated as L1 (leachate after 2 days), L2 (leachate after 4 days), L3 (leachate after 6 days), L4 (leachate after 8 days), L5 (leachate after 10 days), L6 (leachate after 12 days). The research stand for the column experiments is shown in Figure 1.

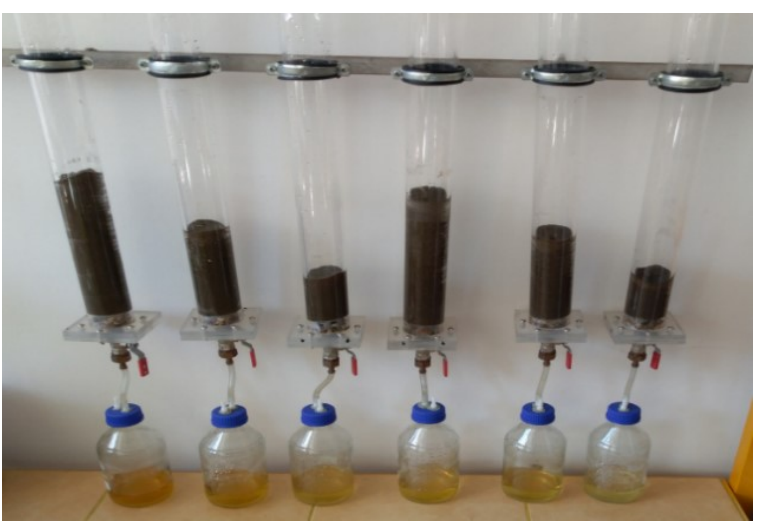

Fig. 1. Stand for column experiments

\section{Results and discussion}

\subsection{Characteristics of research substrates: struvite, soil and soil mixtures}

The analysis of the surface composition of the sediments obtained in laboratory settings from an X-ray diffractometer. The results of the analysis demonstrate that the sediments contain $99 \%$ of the mixture of struvite, its amorphous forms and trace contents of compounds used for synthesis of the compound, and $\mathrm{NaOH}$ used for correction of $\mathrm{pH}$.

Table 1 presents overall characterization of soil and mixtures of soil with various doses of struvite.

Table 1. Physical and chemical properties of test substrates: soil and soil mixtures

\begin{tabular}{|c|c|c|c|c|}
\hline \multirow{2}{*}{ Parameters } & \multicolumn{4}{|c|}{ Substrates } \\
\hline & (M/0.0) & (M/0.1) & $(\mathrm{M} / 0.5)$ & (M/1.0) \\
\hline OM, \% & $3.50 \pm 0.11$ & $3.29 \pm 0.24$ & $3.36 \pm 0.08$ & $3.27 \pm 0.14$ \\
\hline \multirow{2}{*}{$\mathrm{pH},(-)$} & $\begin{array}{c}\mathrm{H}_{2} \mathrm{O}: 7.72 \\
\pm 0.05\end{array}$ & $\begin{array}{l}\mathrm{H}_{2} \mathrm{O}: 7.75 \\
\quad \pm 0.01\end{array}$ & $\begin{array}{c}\mathrm{H}_{2} \mathrm{O}: 7.78 \\
\quad \pm 0.04\end{array}$ & $\begin{array}{c}\mathrm{H}_{2} \mathrm{O}: 7.84 \\
\pm 0.02\end{array}$ \\
\hline & $\begin{array}{c}\text { KCl: } 7.42 \\
\pm 0.02\end{array}$ & $\begin{array}{c}\mathrm{KCl}: 7.4 \pm \\
0.01\end{array}$ & $\begin{array}{c}\text { KCl: } 7.41 \\
\pm 0.01\end{array}$ & $\begin{array}{c}\mathrm{KCl}: 7.45 \\
\pm 0.01\end{array}$ \\
\hline $\begin{array}{l}\text { Total } \\
\text { alkaline } \\
\text { cations, } \\
\text { mmol (+) } \\
/ 100 \mathrm{~g}\end{array}$ & $0.18 \pm 0.03$ & $0.20 \pm 0.05$ & $0.21 \pm 0.07$ & $0.22 \pm 0.1$ \\
\hline $\begin{array}{l}\text { Total } \\
\text { carbon, mg/ } \\
\mathrm{g}\end{array}$ & $\begin{array}{c}14.61 \pm \\
0.02\end{array}$ & $\begin{array}{c}14.78 \pm \\
0.03\end{array}$ & $\begin{array}{c}14.81 \pm \\
0.05\end{array}$ & $14.87 \pm 0.1$ \\
\hline $\begin{array}{l}\text { Total } \\
\text { phosphorus, } \\
\mathrm{mgP}_{2} \mathrm{O}_{5} / \\
100 \mathrm{~g} \text { soil }\end{array}$ & $6.37 \pm 0.11$ & $6.98 \pm 0.21$ & $11.46 \pm 0.13$ & $17.71 \pm 0.17$ \\
\hline $\begin{array}{l}\text { Available } \\
\text { phosphorus, } \\
\mathrm{mg} \mathrm{P} / \mathrm{kg}\end{array}$ & $\begin{array}{c}280.0 \pm \\
0.12\end{array}$ & $\begin{array}{c}311.0 \pm \\
0.09\end{array}$ & $\begin{array}{c}489.0 \pm \\
0.23\end{array}$ & $\begin{array}{c}754.0 \pm \\
0.16\end{array}$ \\
\hline $\begin{array}{l}\text { Total } \\
\text { nitrogen, } \\
\mathrm{mg} / \mathrm{g}\end{array}$ & $0.80 \pm 0.12$ & $0.81 \pm 0.18$ & $0.85 \pm 0.08$ & $0.98 \pm 0.04$ \\
\hline
\end{tabular}

Percentage of the OM for the soil was $3.50 \%$, whereas for the mixtures, it ranged from $3.29 \%$ to $3.36 \%$. Content of total phosphorus for the soil was ca. 440.1 $\mathrm{mg} / \mathrm{kg}$, whereas the contribution of the available forms represented $64 \%$. Total phosphorus content and available forms in the mixtures increased with the increasing of struvite percentage. A noticeable increase in the content of available forms of phosphorus $(90 \%)$ was observed for the mixtures with addition of $0.5 \mathrm{~g}$ and $1 \mathrm{~g}$ struvite. The content of total carbon for soil and the mixtures was at a similar level, ranging from $14,61 \mathrm{mg} / \mathrm{g}$ to 14.87 $\mathrm{mg} / \mathrm{g}$, whereas of total nitrogen was at a low level, from $0.80 \mathrm{mg} / \mathrm{g}$ to $0.98 \mathrm{mg} / \mathrm{g}$. Addition of struvite to soil led to the increase in the content of biogenic elements: total nitrogen and phosphorus, especially in the mixture of soil with $1 \mathrm{~g}$ struvite. The interaction between the solid phase of the soil and the water contained in the soil determines its acid or alkaline character. Some nutrients in acid soils transform into hardly available forms e.g. molybdenum, boron and phosphorus. All the substrates were characterized by an alkaline reaction. Analysis of these parameters showed that the sample is alkaline mineral soil with high phosphorus content. 


\subsection{Analysis of the soil after completion of the experiment}

After completion of the experiments, the soil was removed from the columns, averaged ( 3 columns with different height of soil profile were connected) for each combination and subjected to the analysis as in the case of initial tests. Table 2 contains the results of physical and chemical analysis for all combinations (soil mixtures and soil) after 12 days of running the experiment.

Table 2. Selected physical and chemical properties of test substrates: soil and soil mixtures (after experiment)

\begin{tabular}{|c|c|c|c|c|}
\hline \multirow{2}{*}{ Parameters } & \multicolumn{4}{|c|}{ Substrates } \\
\hline & $(\mathrm{M} / \mathbf{0 . 0})$ & (M/0.1) & $(\mathrm{M} / 0.5)$ & (M/1.0) \\
\hline OM, \% & $\begin{array}{c}3.24 \pm \\
0.26\end{array}$ & $\begin{array}{c}3.05 \pm \\
0.18\end{array}$ & $\begin{array}{c}3.22 \pm \\
0.12\end{array}$ & $\begin{array}{c}3.15 \pm \\
0.24\end{array}$ \\
\hline \multirow{2}{*}{$\mathrm{pH},(-)$} & $\begin{array}{l}\mathrm{H}_{2} \mathrm{O}: 7.82 \\
\quad \pm 0.04\end{array}$ & $\begin{array}{c}\mathrm{H}_{2} \mathrm{O}: 7.66 \\
\pm 0.06\end{array}$ & $\begin{array}{l}\mathrm{H}_{2} \mathrm{O}: 7.68 \\
\quad \pm 0.03\end{array}$ & $\begin{array}{c}\mathrm{H}_{2} \mathrm{O}: 7.60 \\
\pm 0.05\end{array}$ \\
\hline & $\begin{array}{c}\text { KCl: } 7.40 \\
\pm 0.02\end{array}$ & $\begin{array}{c}\text { KCl: } 7.30 \\
\pm 0.08\end{array}$ & $\begin{array}{c}\text { KCl: } 7.28 \\
\quad \pm 0.06\end{array}$ & $\begin{array}{c}\text { KCl: } 7.25 \\
\pm 0.07\end{array}$ \\
\hline $\begin{array}{l}\text { Total alkaline } \\
\text { cations, mmol } \\
\text { (+) } 100 \mathrm{~g}^{-1}\end{array}$ & $\begin{array}{c}0.20 \pm \\
0.08\end{array}$ & $0.22 \pm 0.1$ & $\begin{array}{c}0.21 \pm \\
0.06\end{array}$ & $\begin{array}{c}0.22 \pm \\
0.12\end{array}$ \\
\hline $\begin{array}{l}\text { Total carbon, } \\
\mathrm{mg} / \mathrm{g}\end{array}$ & $\begin{array}{c}16.00 \pm \\
0.55\end{array}$ & $\begin{array}{c}16.34 \pm \\
0.14\end{array}$ & $\begin{array}{c}17.45 \pm \\
0.12\end{array}$ & $\begin{array}{c}18.23 \pm \\
0.57\end{array}$ \\
\hline $\begin{array}{l}\text { Total } \\
\text { phosphorus, } \\
\mathrm{mgP}_{2} \mathrm{O}_{5} / 100 \mathrm{~g} \\
\text { soil }\end{array}$ & $\begin{array}{c}6.074 \pm \\
0.17\end{array}$ & $\begin{array}{c}6.52 \pm \\
0.27\end{array}$ & $\begin{array}{c}10.77 \pm \\
0.13\end{array}$ & $\begin{array}{c}15.35 \pm \\
0.14\end{array}$ \\
\hline $\begin{array}{l}\text { Available } \\
\text { phosphorus, } \\
\text { mg P/kg }\end{array}$ & $\begin{array}{c}248.0 \pm \\
0.15\end{array}$ & $\begin{array}{c}302.0 \pm \\
0.07\end{array}$ & $\begin{array}{c}487.0 \pm \\
0.11\end{array}$ & $\begin{array}{c}675.0 \pm \\
0.05\end{array}$ \\
\hline $\begin{array}{l}\text { Total nitrogen, } \\
\mathrm{mg} / \mathrm{g}\end{array}$ & $\begin{array}{c}0.91 \pm \\
0.21\end{array}$ & $\begin{array}{c}0.98 \pm \\
0.18\end{array}$ & $\begin{array}{c}1.01 \pm \\
0.07\end{array}$ & $\begin{array}{l}1.02 \pm \\
0.03\end{array}$ \\
\hline
\end{tabular}

\pm standard deviation

Since the experiments were conducted for the soil without dedicated vegetation, the content of $\mathrm{OM}$ after completion of the experiment was not significantly changed (decline by 4.1-7.5\%), whereas short duration of examinations prevented the indigenous flora and fauna from mineralization.

An insignificant reduction in the $\mathrm{pH}$ value was found with the increase in struvite content in the soil. Similar to soil and control mixtures, the samples were characterized by an alkaline reaction, with the value of $\mathrm{pH}$ ranging from 7.60 to 7.82 in distilled water, whereas these values of $\mathrm{KCl}$ ranged from 7.25 to 7.40 . The values of $\mathrm{pH}$ decreased with the increasing struvite dose in the samples. Availability of nutrients for plants depends on acidity of soil they grow in [27]. Some nutrients in acid soils transform into hardly available forms e.g. molybdenum, boron and phosphorus [28].

An increase in total carbon and total nitrogen was found with respect to the samples before the experiment. Total carbon increased with the struvite dose in the mixture and was: $16.0 \mathrm{mg} / \mathrm{g}$ for soil without additions, $16.34 \mathrm{mg} / \mathrm{g}$ for the mixture with the dose of $0.1 \mathrm{~g}$ struvite and $17.45 \mathrm{mg} / \mathrm{g}$ and $18.23 \mathrm{mg} / \mathrm{g}$ for samples with 0.5 and $1 \mathrm{~g}$ struvite. The basic factor that impacts on mobility of elements in soil is water, where, depending on the natural or anthropogenic environment, $\mathrm{pH}$ and chemical composition are formed [29].

In the soil sample without struvite and mixtures containing 0.1 and $0.5 \mathrm{~g}$ struvite, the content of phosphorus available to plants declined insignificantly, whereas in the cases of the dose of $1.0 \mathrm{~g}$, it rose to the level of over $97 \%$ of total phosphorus.

\subsection{Analysis of a phosphorus content in the leachate from columns lysimeter}

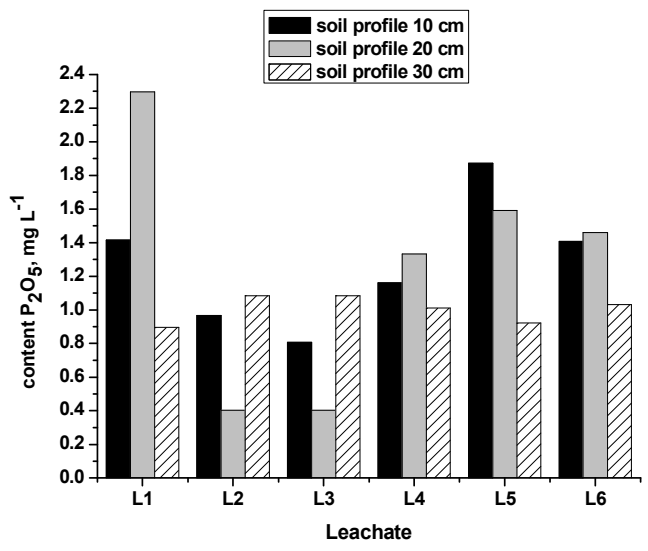

Fig. 2. Content of $\mathrm{P}_{2} \mathrm{O}_{5}$ for the $\mathrm{M} / 0.0$ sample (soil without struvite)

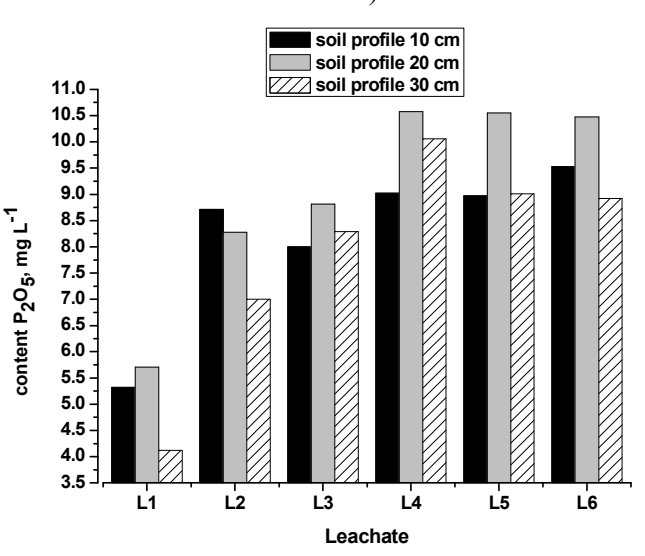

Fig. 3. Content of $\mathrm{P}_{2} \mathrm{O}_{5}$ for the $\mathrm{M} / 0.1$ (Soil $+0.1 \mathrm{~g}$ struvite)

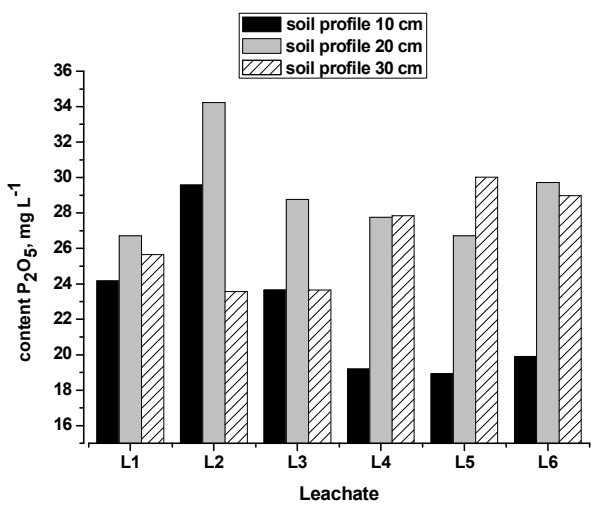

Fig. 4. Content of $\mathrm{P}_{2} \mathrm{O}_{5}$ for the $\mathrm{M} / 0.5$ sample (Soil $+0.5 \mathrm{~g}$ struvite) 
The amount of leached phosphorus is directly related to the dose of struvite in the mixture. As the dose increases, the content of leached into the phosphorus eluate increases. Figs. 2-5 present the content of $\mathrm{P}_{2} \mathrm{O}_{5}$ in leachates recorded for individual heights of soil profiles in the soil samples for consecutive samples of leachates. Analysis of changes in phosphorus content in leachates was based on the means from 3 repetitions.

For the control sample $(\mathrm{M} / 0.0)$, leaching of phosphorus present in soil occurs steadily only in the case of a profile with height of $30 \mathrm{~cm}$, whereas differences in its content in individual leachates reached max. $17.4 \%$. In the case of the samples with height of 10 $\mathrm{cm}$ and $20 \mathrm{~cm}$, substantial variability can be observed, especially noticeable in the first stage of the experiments for the samples with height of $20 \mathrm{~cm}$ : differences in the level of leaching reach up to $80 \%$. In the further part of the experiment, the amount of the leached phosphorus remained at a similar level.

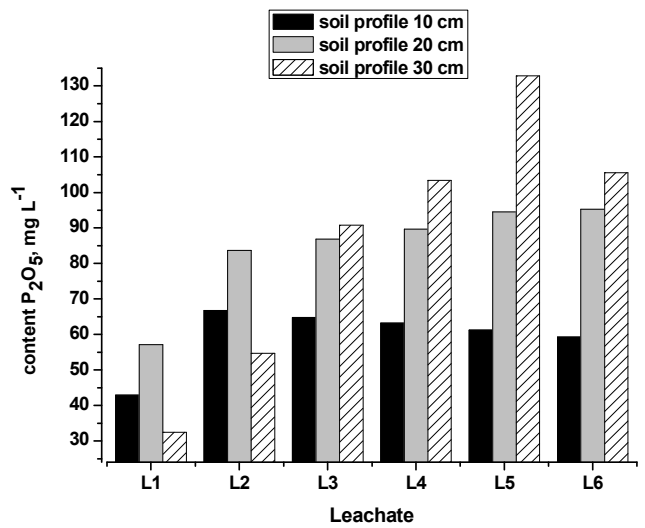

Fig. 5. Content of $\mathrm{P}_{2} \mathrm{O}_{5}$ for the $\mathrm{M} / 1.0$ (Soil $+1.0 \mathrm{~g}$ struvite)

The process of phosphorus leaching from the samples containing $0.1 \mathrm{~g}$ struvite became steady after 4 days of watering, showing a general upward tendency for all the analyzed heights. This dynamics of phosphorus release can suggest stabilization of leaching conditions with time. Maximal content of phosphorus in leachates was $10.05 \mathrm{mg} / \mathrm{L}$.

The lowest regularity can be observed in the process of leaching phosphorus from the soil sample containing $0.5 \mathrm{~g}$ struvite. After half of the experiment time, leaching through the $10 \mathrm{~cm}$ profile became steady, reaching the level of 19-20 mg L-1. After the 6th day of leaching, the level of phosphorus leaching from the sample with height of $20 \mathrm{~cm}$ ranged from 26.7 to $29.7 \mathrm{mg} \mathrm{L}^{-1}$ (variability at the level of $11 \%$ ). After an initial decline, the content of phosphorus leached from the sample with height of $30 \mathrm{~cm}$ showed an upward tendency.

For the struvite dose of $1.0 \mathrm{~g}$, phosphorus leaching process became steady from the 4th day of watering for $10 \mathrm{~cm}$ and $20 \mathrm{~cm}$ samples, whereas for the $10 \mathrm{~cm}$ profile, the tendency was slightly declining (differences at the level of $12.6 \mathrm{~cm}$ ). Furthermore, for the $20 \mathrm{~cm}$ profile, the tendency was slightly upward (differences of $13.8 \%$ ). A strong increasing tendency characterizes leaching the phosphorus from the $30 \mathrm{~cm}$ sample (the longest reaction route), whereas the content of the leached element reached the maximal value of $132.8 \mathrm{mg} \mathrm{L}^{-1}$.

The struvite dose applied to the soil has a direct effect on the amount of leached phosphorus determined in leachates. The results obtained in the study demonstrate that the mechanism of release of phosphorus is similar, regardless of the struvite dose used, whereas the amount of leached phosphorus is proportional to the additive dose used. The examinations revealed the relationship observed by other authors [20; 44] between $\mathrm{pH}$ and the content of leached phosphorus. A decline in the value of this parameter (Table 3 ) results in the increase of phosphorus content in leachates.

The study published by Djodjic et al. (2014) [11] found that specific factors of the soils examined are the indicators of the phosphorus loss following leaching. However, a single universal indicator cannot be found for all the soils studied. Roy (2017) [30] distinguished between the following mechanisms of phosphorus transfer from soil to waters:

- Chemical process of phosphorus solving;

- Physical mechanism of separation and removal of soil particles through erosion;

- Incidental migration of phosphorus from soil to water after application of phosphorus fertilizer or manure in conditions which are not conducive to permeating of this component into the soil structure and with excess water that facilities its washing.

Since this study represents an initial analysis of phosphorus leaching from soils enriched in struvite, the mechanism of this phenomenon cannot be unequivocally demonstrated at this stage. Therefore, the authors are designing another series of experiments which will allow for explanation of this process.

\section{Conclusions}

It was found that the struvite dose applied to the soil has a direct effect on the amount of leached phosphorus. Furthermore, the results obtained in the study demonstrate that the mechanism of release of phosphorus remains the same, regardless of the struvite dose used and that the amount of leached phosphorus is proportional to the additive dose used.

The highest phosphorus concentrations were observed for the height of $20 \mathrm{~cm}$ of soil profile for the dose of $0.1 \mathrm{~g}$ struvite. In the case of higher doses of struvite, i.e. $1.0 \mathrm{~g}$, the highest concentration was found for the height of $30 \mathrm{~cm}$. A decline in the concentration of the leached phosphorus was observed after the sixth sampling of the eluate, which resulted from leaching the soil profile with simulated annual rainfall amount. It should be expected that further washing of the bed will lead to leaching smaller doses of soluble phosphorus until depletion of its soluble forms.

\section{Acknowledgement}

Publication supported by the Polish Ministry of Science and Higher Education as a part of the program of 
activities disseminating science from the project ,Organization of the First International Science Conference - Ecological and Environmental Engineering”, 26-29 June 2018, Kraków.

The research was funded by the project No. BS/MN401/310/17.

\section{References}

1. R.W. McDowell, A.N. Sharpley, L.M. Condron, P.M. Haygarth, P.C. Brookes, Soil Biology, 100, pp. 269-284 (2011)

2. C. Jouany, P. Cruz, T. Daufresne, M. Duru, Soil Biology, 100, pp 275-294 (2011)

3. P. Szpak, J.F. Millaire, Ch.D. White, F.J. Longstaffe, Journal of Archaeological Science, 39, pp. 37213740 (2012)

4. T. Balemil, K. Negisho, Journal of Soil Science and Plant Nutrition, 12, 3, 547-561 (2012)

5. A. Szaja, Annual Set The Environment Protection, 15, pp. 361-370 (2013)

6. D.P. van Vuuren, A.F. Bouwman, A.H.W. Beusen, Global Environmental Change, 20(3), pp. 428-439 (2010)

7. J.D. Doyle, S.A. Parsons, Water Res, 36, pp. 39253940 (2002)

8. K. Daekeun, K. Jinhyeong, R. Hong-Duck, L. SangIII, Bioresource Technology, 100, 74-78 (2009)

9. L. Pastor, D. Mangin, J. Ferrer, A. Seko, Bioresource Technology, 101, pp. 118-125 (2010)

10. L.E. de-Bashan, Y. Bashan, Water Research 38, 19, pp. 4222-4246 (2004)

11. F. Djodjic, K. Börling, L. Bergström, Journal of Environmental Quality, 33, 2, pp. 678-684 (2004)

12. J.J. McDonnell, M. Sivapalan, K. Vache, S. Dunn, G. Grant, R. Haggerty, C. Hinz, R. Hooper, J. Kirchner, M.L. Roderick, J. Selker, M. Weiler, Water Resources Research, 43, W07301.1W07301.6.(2007)

13. D. McDonald, K. Reid, Phosphorus Leaching? In: Agronomy Guide for Field Crops. Ed. Ch. Brown. Toronto. OMAFRA (2003)

14. M. Weiler, J.J. McDonnell, Water Resources Research, 43, W03403.1 - W03413.13 (2007)
15. G.S. Toor, L.M. Condron, H.J. Di, K.C. Cameron, B.J. Cade-Menun, Soil Biology and Biochemistry, 35, pp. 1317-1323 (2003)

16. A.J. Morris, D. Hesterberg, Australian Society of Soil Science Incorporated, pp. 37- 39 (2010)

17. F.R. Li, W.Z. Zhao, J.L. Liu, Z.G. Huang, Plant Soil. 317, pp. 79-92 (2009)

18. L. Chapuis-Lardy, R.C. Le Bayon, M. Brossard, D. López-Hernández, E. Blanchart, Soil Biology, 100, pp. 199-213 (2011)

19. G.J. Lair, F. Zehetner, Z.K. Khan, M.H. Gerzabek, Geoderma, 149, pp. 39-44 (2009)

20. EN 1997-2:2007; Eurocode 7 -Geotechnical design Part 2: Ground investigation and testing.

21. ISO 10390:2005; Soil quality -- Determination of $\mathrm{pH}$.

22. A. Karczewska, C. Kabała, Methods of laboratory analyses of soil and plants, Version 4, Agricultural University in Wroclaw, Wroclaw (2005).

23. PN-EN 15936:2013-02E Sludge, treated biowaste, soil and waste - Determination of total organic carbon (TOC) by dry combustion.

24. ISO 6878:2004; Water quality - Determination of phosphorus - Ammonium molybdate spectrometric method.

25. H. Riehm, Agrochimica, 3, pp. 49 - 65 (1958)

26. D.A. Hornec, R.O. Miller, Determination of total nitrogen in plant tissue. In: Handbook of Reference Methods for Plant Analysis. Ed. Yash P. Kalra, CRC Press, Taylor \& Francis Group (1998)

27. A. Mocek, Soil science, PWN Scientific Publisher (2015)

28. A. Handzel, J.B. Królczyk, A.E. Latawiec, K. Pluta, D. Malina, A. Sobczak-Kupiec, Analysis of physicochemical properties of soils and determination of selected elements, Infrastructure and Ecology of Rural Areas - Infrastructure And Ecology of Rural Areas, POLISH ACADEMY OF SCIENCES, Branch in Cracow, Technical Committee of Rural Infrastructure, No. I / 2, 419-432 (2017)

29. K. Nowińska, Z. Adamczyk, Mining and Geology, 8, pp. 77-87 (2013)

30. E.D. Roy, Ecological Engineering, 98, pp. 213-227 (2017) 